\title{
FOREWORD
}

Since 1923, the American Law Institute (ALI) has sought to "restate" American law. This means seeking coherent and progressive doctrine in the confusion of common-law decisions by judges. Note that unlike countries with a unified legal system, the United States has fifty states, each with its own rules as to many areas of public and private law. The ALI, a private organization, is a primary source of legal unification.

The Institute has also worked on reforming other areas of law, for example criminal law and tax law. And in recent years it has sought to be helpful internationally, for example in the project on Transnational Civil Procedure, cosponsored with Unidroit, and in its attempt to assist coordination of transnational bankruptcies in Canada, Mexico, and the United States. Aside, however, from a chapter in our Restatement Third, the Foreign Relations Law of the United States, which antedated the present World Trade Organization regime, the current project represents the Institute's first effort to engage with trade law.

The law of international trade is at an early stage of development. Trade, of course, is old, and so are bilateral and some multilateral attempts to establish rules. But the World Trade Organization (WTO), with its elaborate dispute-resolution system, is only nine years old, and so far there have been fewer than sixty decisions by the Appellate Body. Attempting to describe rules of trade law is like authoring a treatise on contract law in England in the year 1200, when the King's Bench had rendered a similarly modest number of opinions.

Nonetheless, the effort to build legal principles on the framework of the WTO decisions seems worthwhile. If talented economists and lawyers analyze the decisions, those engaged in the process can be drawn into conversation and over time there will be agreement on basic concepts. This will not happen quickly, but the significance for the world economy is great and assisting the effort, even modestly, will be valuable.

This project, whose working title is Principles of Trade Law: The World Trade Organization, is new for the ALI in two ways. First, each portion of 
the work is being undertaken by both a lawyer and an economist. Second, the two leaders of the project, Henrik Horn of Stockholm University and Petros Mavroidis of the University of Neuchâtel and Columbia Law School, are not Americans. The two Chief Reporters selected three other lawyer/economist teams and the four teams each analyzed a group of 2001 decisions by the adjudicating bodies of the WTO. Those analyses were themselves subjected to critical analysis by the other Reporters at a meeting in October and then by an international group of experts on the law and economics of the world trading system at a two-day invitational conference in February. The resulting set of Reporters' Studies is included in this volume.

As I write, the team of scholars, to which another lawyer and economist have been added, has begun work analyzing the decisions rendered by the WTO in 2002. Our plan is to carry out this "bottom-up" process of analyzing individual trade law decisions for several more years, and only then to attempt to draft general principles based on the analysis of the individual disputes. It should be noted that this preliminary series of Reporters' Studies, of which the present volume represents the first installment, is the work of the participating Reporters themselves rather than of the American Law Institute. We envision these Studies, of tremendous value and importance in their own right, as constituting the essential matrix for developing the broader formulations that we hope eventually to be able to issue under the aegis of the Institute itself.

We are immensely grateful to our Reporters and to those who have criticized the earlier drafts of their work. We are also grateful for the financial support that has made this project possible from Jan Wallander's and Tom Hedelius' Research Foundation, Svenska Handelsbanken, Stockholm, from the Asia-Pacific Economic Cooperation Study Center at Columbia University, and from the Milton and Miriam Handler Foundation.

This is challenging work, but we begin the undertaking confident that our efforts can assist in a small way in the creation of a peaceful and prosperous world.

Lance Liebman

Director

The American Law Institute 


\section{A note on the American Law Institute}

The American Law Institute was founded in 1923 and is based in Philadelphia. The Institute, through a careful and deliberative process, drafts and then publishes various restatements of the law, model codes, and other proposals for legal reform "to promote the clarification and simplification of the law and its better adaptation to social needs, to secure the better administration of justice, and to encourage and carry on scholarly and scientific legal work." Its membership consists of judges, practicing lawyers, and legal scholars from all areas of the United States as well as some foreign countries, selected on the basis of professional achievement and demonstrated interest in the improvement of the law. The Institute's incorporators included Chief Justice and former President William Howard Taft, future Chief Justice Charles Evans Hughes, and former Secretary of State Elihu Root. Judges Benjamin N. Cardozo and Learned Hand were among its early leaders.

The Institute's restatements, model codes, and legal studies are used as references by the entire legal profession.

The American Law Institute http://www.ali.org 